\title{
Analisis Tipologi Variabel Strategis pada Pengembangan Kawasan Ekowisata Kedung Ombo
}

\author{
Nafiah Ariyani ${ }^{1}$ \\ Universitas Sahid, Jakarta, Indonesia
}

\author{
Akhmad Fauzi \\ Instititut Pertanian Bogor, Bogor, Indonesia
}

Artikel Masuk : 28 Oktober 2018

Artikel Diterima : 3 Desember 2019

Tersedia Online : 31 Desember 2019

\begin{abstract}
Abstrak: Kawasan Waduk Kedung Ombo yang kaya sumber daya alam sangat potensial untuk dikembangkan sebagai kawasan ekowisata, namun permasalahan kelembagaan dan bias fokus kebijakan telah menghambat pengembangannya. Penelitian ini bertujuan untuk mengidentifikasi variabel-variabel strategis di Kawasan Waduk Kedung Ombo dan menemukan deskripsi hubungan interdependensi antara variabel-variabel tersebut, yang bermanfaat dalam penentuan kebijakan yang tepat. Penelitian dan pengumpulan data dilakukan melalui diskusi kelompok terfokus dan lokakarya. Analisis data dilakukan dengan menggunakan metode Micmac. Hasil penelitian menentukan tiga puluh satu variabel strategis dalam pengembangan kawasan ekowisata Kedung Ombo yang dikelompokkan ke dalam tipologi sebagai berikut: (1) variabel determinan, terdiri dari: regulasi dan izin khusus; (2) variabel relay, terdiri dari: keterlibatan masyarakat, potensi usaha wisata, kesiapan infrastruktur, sadar wisata, transportasi, wisatawan, atraksi wisata, akomodasi, promosi pariwisata, jasa wisata, invetasi swasta, tata kelola, koordinasi, peran aparatur dan informasi; (3) variabel otonom, terdiri dari: kemampuan kewirausahaan lokal, pemahaman pengembang terhadap norma lokal, keindahan alam, daya dukung lingkungan, dan aksesibilitas; dan (4) variabel dependen terdiri dari: penghasilan pajak, penghasilan retribusi, ketersedian dana untuk masyarakat, kelestarian kearifan lokal, perluasan lapangan kerja, konservasi fungsi waduk, kelestarian hutan, peningkatan kesejahteraan, dan penurunan angka kemiskinan. Penelitian ini juga menghasilkan urutan skala prioritas dari variabel-variabel strategis tersebut yang sangat berguna bagi pengambil kebijakan dalam mengarahkan fokus kebijakan untuk menjamin keberhasilan pengembangan kawasan ekowisata Kedung Ombo secara berkelanjutan.
\end{abstract}

Kata Kunci: ekowisata; Kedung Ombo; Micmac; variabel strategis

Abstract: The Kedung Ombo Reservoir area, which is rich in natural resources, has the potential to be developed as an ecotourism area, but institutional issues and policy focus bias have hampered its development. This study aims to identify strategic variables in the region and find a description of the interdependent relationship between these variables, which is useful in determining the right policy. Research data were obtained through focus group

\footnotetext{
${ }^{1}$ Korespondesi Penulis: Universitas Sahid, Jakarta, Indonesia

Email: arienafiah@gmail.com
} 


\section{Analisis Tipologi Variabel Strategis pada Pengembangan Kawasan Ekowisata Kedung Ombo}

discussions and workshops. Data analysis using Micmac method. The results of the study determine 31 (thirty one) strategic variables in the development of the Kedung Ombo ecotourism area which are grouped into typologies as follows: (1) determinant variables, consisting of: special regulations and permits; (2) relay variable, consisting of: community involvement, tourism business potential, infrastructure readiness, tourism awareness, transportation, tourists, tourist attractions, accommodation, tourism promotion, tourism services, private investment, governance, coordination, role of apparatus and information; (3) autonomous variables, consisting of: local entrepreneurial abilities, developer's understanding of local norms, natural beauty, environmental carrying capacity, and accessibility; and (4) dependent variables such as: tax income, retribution income, availability of funds for the community, preservation of local wisdom, expansion of employment opportunities, conservation of reservoir functions, forest preservation, welfare improvement, and poverty reduction. This research also produces a sequence of priority scales of these strategic variables which is very useful for policy makers in directing the focus of policies to ensure the successful development of the Kedung Ombo ecotourism in a sustainable manner.

Keywords: ecotourism; Kedung Ombo; Micmac; strategic variables

\section{Pendahuluan}

Pariwisata menjadi sektor yang terus tumbuh dan dinilai oleh para pakar sebagai sektor dengan pertumbuhan tercepat. Sektor ini dianggap memiliki tingkat efektivitas tinggi dalam penciptaan lapangan kerja dan pendapatan (Anup, 2016). Banyak negara menetapkan pariwisata sebagai sumber alternatif pembangunan yang diharapkan menjadi kekuatan ekonomi baru seiring dengan ketersediaan sumber daya alam yang semakin berkurang (Erdogan \& Erdogan, 2010).

Salah satu subset pariwisata yang paling cepat berkembang adalah ekowisata (Diamantis, 1999) yaitu pariwisata yang berfokus pada kelestarian lingkungan. Ekowisata dinilai memiliki efek positif pada lingkungan alam dengan tetap mempertimbangkan kelayakan ekonomi dan keadilan sosial jangka panjang (McKinney, 2016). Ekowisata juga dinilai telah mendorong munculnya kepekaan terhadap budaya dalam hubungan antara pengunjung dan penduduk lokal dan bertindak sebagai katalis pembangunan berkelanjutan (Sindiga, 1999). Namun demikian, tetap perlu dicermati khususnya oleh perencana pariwisata terkait dengan semakin menurunnya kualitas hutan alam yang terjadi di Asia, Afrika dan Amerika Latin seiring dengan perkembangan ekowisata yang pesat di wilayah ini (Erdogan \& Erdogan, 2010).

Sebagai bagian dari sektor pariwisata yang multidimensi, tidak ada definisi khusus tentang ekowisata yang diterima secara universal. Berbagai definisi yang ada selama ini mencerminkan paradigma dan perspektif yang beragam (Sindiga, 1999). Umumnya, ekowisata mewakili istilah umum yang mencakup: (1) wisata alam dan petualangan seperti arung jeram, bungee jumping, panjat tebing, bersepeda gunung, layang luncur di area alami; (2) wisata budaya, seperti mengamati dan bergaul di antara masyarakat adat; dan (3) wisata sains berupa darma wisata pada kawasan lindung, mengunjungi dan berkemah di taman nasional dan wisata warisan (Erdogan \& Erdogan, 2010).

Keberhasilan ekowisata ditentukan oleh banyak variabel, yaitu: sumber daya lingkungan, agen-agen utama dalam rantai pasokan pariwisata, tata kelola pada destinasi wisata, faktor-faktor pelengkap yang meningkatkan daya saing destinasi wisata, dan dimensi-dimensi yang berkaitan dengan keamanan (Rodríguez-Díaz \& Espino Rodríguez, 2016). Di antara variabel-variabel tersebut, variabel tata kelola dan kelembagaan dipandang sebagai variabel paling penting seiring dengan banyaknya pihak yang terlibat dalam pengelolaan suatu destinasi wisata dan adanya perubahan kewenangan pengambilan 
keputusan dari yang awalnya terpusat pada pemerintah menjadi melibatkan sektor swasta (Beritelli, Bieger, \& Laesser, 2007).

Sebagai negara yang kaya sumber daya alam, Indonesia mempunyai kesempatan yang sangat luas untuk mengembangkan ekowisata. Salah satu daerah yang potensial sebagai destinasi ekowisata adalah kawasan waduk Kedung Ombo di Jawa Tengah. Kawasan Waduk Kedung Ombo mempunyai potensi wisata alam yang sangat besar. Hamparan air waduk yang luas (panjang $1.8 \mathrm{~km}$, lebar $18 \mathrm{~m}$, tinggi $96 \mathrm{~m}$, debit air 723 juta $\mathrm{m}^{3}$ ), berada di kawasan hutan jati yang kaya dengan keanekaragaman hayati, bukit-bukit alami dan panorama yang sangat indah, merupakan karunia alam yang sangat tepat untuk dikembangkan sebagai kawasan ekowisata. Namun, sejak diresmikan pada tahun 1999 potensi tersebut belum diberdayakan secara optimal (Hutagalung \& Sabar, 2015; Nasrudin, 2017; Ngatwanto \& Indrawati, 2018). Meskipun telah ada pengembangan, namun sifatnya lokal, terbatas dan dengan pengelolaan yang terkesan seadanya. Hal tersebut terkait dengan kapasitas pengembang yang sangat terbatas yaitu masyarakat lokal dan pemerintah desa (Isnaini, 2008; Taofiq, Asrori, \& Iswati, 2015). Sebagian dari objek tersebut bahkan tidak memenuhi perizinan, sehingga keberadaanya tidak berkelanjutan.

Kawasan Kedung Ombo mewakili kompleksitas permasalahan kelembagaan. Hal ini terkait dengan lokasinya yang terletak di antara tiga wilayah kabupaten, yaitu Grobogan, Sragen dan Boyolali. Dari wilayah hutan yang melingkupinya, terletak di wilayah Perhutani Kesatuan Pengelolaan Hutan (KPH) Telawah dan Gundih. Dari aspek operasionalisasi waduk ditangani oleh Balai Besar Wilayah Sungai (BBWS) Pemali Juana, yang merupakan representasi pemerintah pusat (Kementerian Pekerjaan Umum dan Perumahan Rakyat). Pihak-pihak ini menjadi pemangku kepentingan utama pada level menengah dalam pengelolaan dan pengembangan kawasan Kedung Ombo. Namun rendahnya koordinasi telah menjebak pada situasi ego sektoral, dengan masing-masing pihak hanya fokus pada kepentingannya. Jika pihak-pihak tersebut berkolaborasi mengembangkan potensi yang besar tersebut menjadi kawasan ekowisata, selain keberadaanya akan berkelanjutan juga akan memberi dampak positif terhadap perluasan lapangan kerja, kelayakan infrastruktur dan kelestarian hutan yang masih menjadi permasalahan yang cukup besar di wilayah ini.

Salah satu faktor yang akan membantu keberhasilan pengembangan potensi pariwisata kawasan Kedung Ombo adalah adanya peta tentang faktor-faktor strategis yang harus diperhatikan oleh pengambil kebijakan. Dalam rangka memenuhi hal tersebut, penelitian ini dilakukan dengan tujuan untuk mengidentifikasi variabel-variabel strategis di Kawasan Kedung Ombo dengan mendeskripsikan intensitas pengaruh dan hubungan interdependensi antara variabel-variabel baik langsung dan tidak langsung, dan menstratifikasinya dalam urutan paling penting hingga sangat tidak penting. Temuan penelitian ini akan membantu pengambil kebijakan dalam memahami hubungan antarvariabel strategis dan mengarahkan untuk fokus pada variabel yang paling menentukan guna menjamin keberhasilan pengembangan. Dengan mendasarkan pada temuan penelitian ini, diharapkan akan tersusun strategi jangka panjang yang berkualitas, terhindarkan dari masalah yang mungkin timbul di kemudian hari serta mendorong pemikiran ke masa depan yang berhasil untuk mewujudkan kawasan ekowisata Kedung Ombo yang berkelanjutan.

\section{Metode Penelitian}

Penelitian ini menggunakan paradigma struktural prospektif untuk mengeksplorasi struktur, dinamika dan jaringan interelasi antarvariabel yang dinilai paling penting dalam pengembangan kawasan ekowisata Kedung Ombo. Pengumpulan data dilakukan dengan metode diskusi kelompok terfokus (Focus Group Discussion/FGD) untuk menentukan variabel-variabel yang berpengaruh dan menentukan dalam pengembangan kawasan 
ekowisata Kedung Ombo dan lokakarya dalam proses pengisian perangkat lunak yang digunakan dalam analisis data. Pelaksanaan diskusi menggunakan metode world café untuk mendorong terjadinya interaksi, berbagi pengetahuan dan transfer pengalaman di antara peserta. Peserta FGD berjumlah dua puluh orang mewakili pemangku kepentingan di Kawasan Kedung Ombo yang berasal dari Pemerintah Kabupaten Grobogan, Boyolali dan Sragen, BBWS Pemali Juana, Perhutani KPH Telawah dan Gundih, Perguruan Tinggi, Pemerintah Desa, tokoh masyarakat dan pemuda.

Analisis data menggunakan Metode Micmac (Cross Impact Matrix Multiplication Aplied to Classification). Micmac adalah perangkat lunak yang dikembangkan oleh Institut d'Innovation Informatique pour I'Entreprise (Godet, 2000), untuk memperbarui metode analisis struktural dari yang sebelumnya berbentuk kualitatif menjadi kuantitatif (Maria del Mar Delgado-Serrano, Ambrosio-Albalá, \& Francisco, 2015). Dalam operasinya Micmac menerapkan properti matriks (Arcade, Godet, Meunier, \& Roubelat, 1999; Durance et al., 2006). Tujuan dari Micmac adalah untuk mengidentifikasi dan menganalisis variabelvariabel utama dari suatu sistem.

Keunggulan Micmac dibandingkan dengan metode struktural yang lain adalah memungkinkan terjadinya pengelompokan dan penentuan hierarki variabel strategis dari suatu sistem serta mengetahui pengaruh timbal baliknya. Fitur ini sangat bermanfaat dalam proses pengambilan kebijakan karena akan mengarahkan fokus dari kebijakan, mengingat sering kali fokus kebijakan mengarah pada variabel-variabel yang tidak relevan sehingga mengakibatkan kegagalan. Penjelasan yang disajikan oleh analisis Micmac akan menciptakan keyakinan dan kepercayaan yang lebih besar atas permasalahan yang diajukan dan menyajikan asumsi yang beragam (Benjumea-Arias, Castañeda, \& ValenciaArias, 2016).

Operasionalisasi metode Micmac terdiri dari beberapa tahap, yaitu: (1) pendefinisian masalah, identifikasi variabel internal dan eksternal; (2) penilaian hubungan antarvariabel menurut tingkat pengaruh dan ketergantungan, yang dinilai dengan skala peringkat antara: 0 = tidak ada, $1=$ lemah, 2 = sedang, $3=$ kuat, $\mathrm{P}=$ potensial. Hasil penilaian akan mengualifikasi intensitas pengaruh antarvariabel ke dalam kelompok pengaruh langsung, pengaruh tidak langsung dan pengaruh potensial. Pengaruh langsung terjadi jika variabel $\mathrm{A}$ memiliki efek pada variabel $\mathrm{B}$; pengaruh tidak langsung terjadi jika variabel $\mathrm{A}$ mempengaruhi $B$ dan $B$ mempengaruhi variabel $C$, dan dengan demikian $C$ secara tidak langsung dipengaruhi oleh A. Pengaruh potensial terjadi jika variabel A seharusnya berpengaruh terhadap B, sedangkan tidak ada pengaruh langsung terjadi jika suatu variabel tidak berpengaruh terhadap variabel lain (María del Mar Delgado-Serrano et al., 2016); (3) menganalisis intensitas pengaruh dan ketergantungan variabel yang ditentukan oleh letak variabel pada peta kuadran pengaruh dan ketergantungan variabel (Gambar 1).

Gambar 1 membantu menganalisis pengaruh dan ketergantungan variabel sistem dan mengelompokkannya menjadi empat tipologi yang meliputi variabel determinant, variabel relay, variabel otonom, dan variabel output. Variabel determinant, yaitu variabel yang sangat berpengaruh dan sedikit tergantung pada variabel lainnya. Variabel-variabel ini dianggap sebagai masukan dan sangat menentukan mobilitas sistem. Variabel determinan merupakan variabel yang sangat penting dan membutuhkan perhatian pengambil kebijakan secara maksimal karena sangat memengaruhi variabel-variabel lainnya. Variabel relay (stake variable) disebut juga variabel kunci. Variabel relay sifatnya sangat berpengaruh sekaligus sangat tergantung pada variabel lain. Variabel ini paling tidak stabil karena pengaruh apapun yang terjadi pada mereka dapat mengalir ke seluruh sistem. Variabel relay juga disebut faktor ketidakstabilan karena memiliki "boomerang efect" pada sistem, artinya tindakan terhadap variabel ini akan memengaruhi arah mobilitas sistem. Variabel autonomous (otonom) adalah variabel yang memiliki pengaruh kecil dan sedikit bergantung dengan variabel lainnya. Variabel ini memiliki potensi rendah untuk menghasilkan 
perubahan (inersia trend) terhadap sistem. Variabel otonom disebut juga sebagai variabel excluded. Variabel otonom dibedakan menjadi variabel terputus (disconnecterd variable) dan variabel pengungkit sekunder (secondary levers) (Albala, Lozano, \& Hernández, 2009). Variabel terputus letak maupun evolusinya dekat dengan titik origin, karena itu dapat dikeluarkan dari dinamika sistem. Sedangkan variabel pengungkit sekunder terletak di atas garis diagonal, dengan tindakan tertentu variabel ini dapat memperkuat sistem. Variabel output atau juga disebut variabel dependen. Variabel output menjelaskan dampak yang dihasilkan dari variabel lain, terutama variabel determinant dan variabel relay. Variabel ini terletak di bagian tenggara peta kuadran. Lokasi variabel output menunjukkan variabel yang sedikit mempunyai pengaruh dengan ketergantungan yang tinggi, sehingga variabel tersebut sangat sensitif terhadap faktor-faktor yang mempengaruhi. Variabel ini menjadi indikator deskriptif dari evolusi sistem.

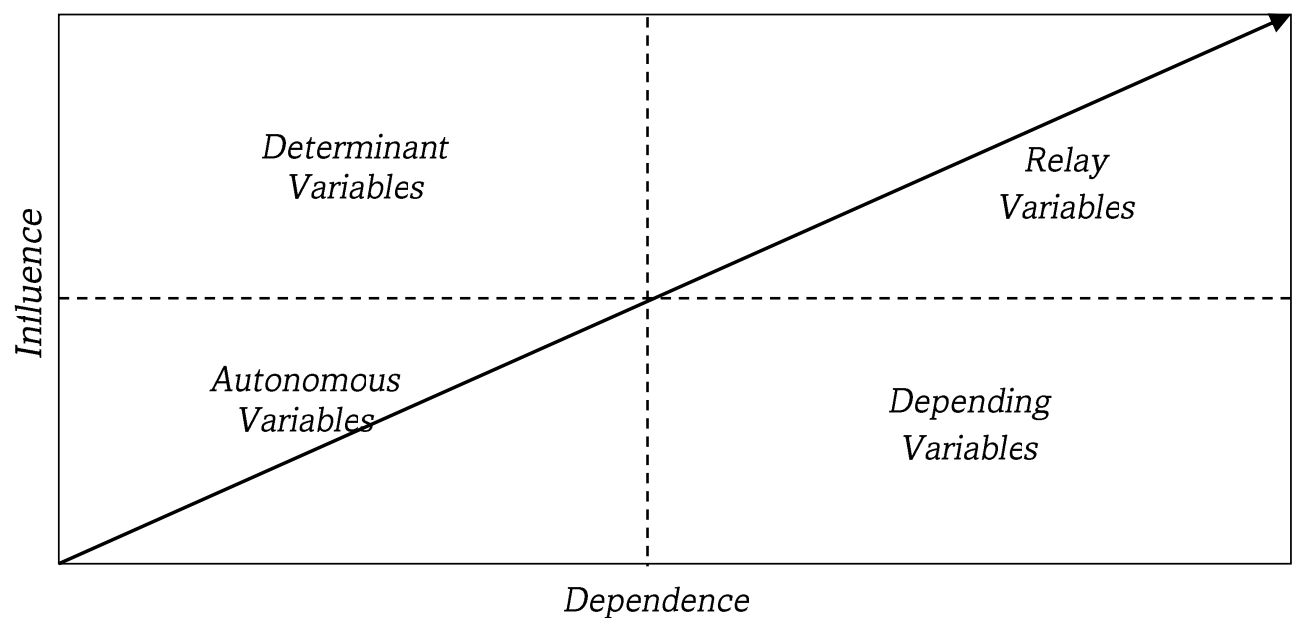

Sumber: Elmsalmi \& Hachicha, 2013

\section{Gambar 1. Peta Pengaruh-Ketergantungan Variabel}

\section{Hasil dan Pembahasan}

Hasil penelitian ini sangat ditentukan oleh kecermatan narasumber dalam mengidentifikasi variabel-variabel yang diperkirakan berpengaruh dalam pengembangan ekowisata Kedung Ombo. Untuk menjangkau hal tersebut, maka pada tahap awal FGD peserta diberikan orientasi oleh pakar tentang konsep ekowisata. Setelah itu, daftar variabel dibuat berdasarkan pemahaman, pengetahuan dan pengalaman peserta. Hasil diskusi mengidentifikasi tiga puluh satu variabel yang dinilai berpengaruh pada pengembangan kawasan ekowisata Kedung Ombo. Variabel-variabel kunci tersebut dikelompokkan dalam tujuh kluster faktor pembentuk pembangunan destinasi wisata alam sebagaimana ditampilkan pada Tabel 1.

Variabel-variabel tersebut kemudian disusun pada perangkat lunak Micmac pada Matrix of Direct Influence (MDI) untuk menentukan intensitas pengaruh masing-masing variabel. MDI merupakan matriks dasar untuk menyusun Matrix of Indirect Influence (MII) yang menunjukkan intensitas pengaruh tidak langsung variabel, dan Matrix Potential of Direct Influence (MPDI) yang memproyeksi intensitas pengaruh variabel jika terjadi perubahan sistem (di kemudian waktu). 


\section{Matrix of Direct Influence (MDI)}

MDI adalah matriks asli dan merupakan data input pada metode Micmac. MDI diisi dengan nilai berkisar antara 0-3 dan $\mathrm{P}$ untuk menentukan intensitas pengaruh langsung dan dipengaruhi langsung tiap variabel terhadap variabel lainnya. Hasil pengisian MDI menentukan posisi variabel pada peta pengaruh dan ketergantungan langsung ke dalam empat tipologi seperti yang ditampilkan pada Gambar 2, yaitu: variabel determinan, yang dihasilkan dari analisis Micmac, dihasilkan dua variabel yang masuk pada kuadran determinan yaitu: K3 (regulasi) dan K2 (izin khusus). Regulasi dan izin khusus yang dimaksud dalam penelitian ini adalah pengaturan tentang penggunaan kawasan waduk dan hutan untuk pariwisata. Kedua variabel tersebut mewakili masalah kelembagaan yang sangat krusial di kawasan ini, karena kewenangan penetapan regulasi dan perizinan khusus bukan berada pada level meso namun pada tataran pemerintahan yang lebih tinggi yaitu: Kementerian Pekerjaan Umum dan Perumahan Rakyat (PUPR) dan Kementerian Kehutanan serta Provinsi Jawa Tengah. Apabila temuan ini ditindaklanjuti oleh pihak-pihak yang paling berwenang tersebut, maka akan menjadi terobosan yang sangat tepat dalam menghadapi permasalahan ego sektoral antara lembaga-lembaga utama tingkat menengah di Kawasan Kedung Ombo, yang hingga saat ini belum menemukan titik temu dan terkesan buntu. Keberadaan regulasi dan izin khusus penggunaan kawasan waduk Kedung Ombo akan menentukan dinamika variabel pada kuadran lainnya.

Tabel 1. Daftar Variabel Strategis Pengembangan Kawasan Ekowisata Kedung Ombo

\begin{tabular}{|c|c|c|c|c|c|}
\hline Kluster & Variabel & Kode & Kluster & Variabel & Kode \\
\hline & Keindahan alam & A1 & \multirow{6}{*}{ 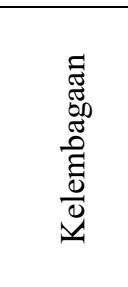 } & Tata Kelola & $\mathrm{K} 1$ \\
\hline ప్ & Daya dukung lingkungan & $\mathrm{A} 2$ & & Izin khusus & $\mathrm{K} 2$ \\
\hline & Aksesibilitas & A3 & & Regulasi & K3 \\
\hline \multirow{5}{*}{$\begin{array}{l}\bar{\pi} \\
\text {. } \\
0 \\
0\end{array}$} & Keterlibatan masyarakat & S1 & & Koordinasi & K4 \\
\hline & $\begin{array}{l}\text { Pemahaman pengembang } \\
\text { terhadap norma lokal }\end{array}$ & S2 & & Peran aparatur & K5 \\
\hline & Lapangan kerja & S3 & & Informasi & K6 \\
\hline & Kesejahteraan masyarakat & S4 & \multirow{6}{*}{ 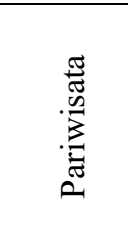 } & Sadar wisata & P1 \\
\hline & Kemiskinan & S5 & & Wisatawan & $\mathrm{P} 2$ \\
\hline \multirow{6}{*}{ 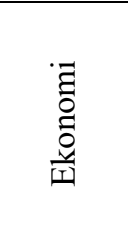 } & Potensi usaha wisata & E1 & & Atraksi wisata & P3 \\
\hline & Kemampuan wirausaha lokal & E2 & & Akomodasi & P4 \\
\hline & Pendapatan pajak & E3 & & Promosi pariwisata & P5 \\
\hline & Pendapatan retribusi & E4 & & Jasa pariwisata & P6 \\
\hline & Dana untuk masyarakat & E5 & \multirow{4}{*}{ 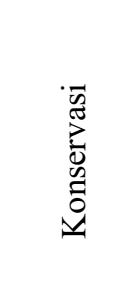 } & Fungsi waduk & KN1 \\
\hline & Investasi swasta & E6 & & Kelestarian hutan & KN2 \\
\hline & Kesiapan infrastruktur & I1 & & Kearifan lokal & KN3 \\
\hline 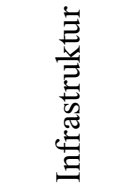 & Transportasi & $\mathrm{I} 2$ & & & \\
\hline
\end{tabular}

Sumber: Hasil FGD Pengembangan Kawasan Ekowisata Kedung Ombo, 2018

Variabel relay adalah variabel terpenting dan dibutuhkan perhatian maksimum dari pengambil kebijakan. Dalam perspektif sistem, variabel yang terletak pada kuadran ini adalah elemen proses yang akan sangat menentukan output. Terdapat lima belas variabel yang termasuk pada kuadran ini, yaitu: potensi usaha wisata (E1), S1 keterlibatan masyarakat (S1), kesiapan infrastruktur (I1), sadar wisata (P1), transportasi (I2), wisatawan (P2), atraksi wisata P3), akomodasi (P4), promosi pariwisata (P5), jasa wisata (P6), invetasi swasta (E6), tata kelola (K1), koordinasi K4), peran aparatur (K5), dan informasi (K6). Variabel-variabel ini harus menjadi fokus perhatian para kepala daerah terkait, kepala 
Perhutani dan Kepala BBWS untuk mewujudkan kawasan ekowisata Kedung Ombo. Dari segi jumlah, variabel pada kuadran ini berjumlah lebih banyak dibandingkan tipologi variabel lainnya, hal ini menggambarkan kestabilan sistem yang dianalisis.

Variabel otonom, meliputi: keindahan alam (A1), daya dukung lingkungan (A2), aksesibilitas (A3), pemahaman pengembang terhadap norma lokal (S2), dan kemampuan wirausaha lokal (E2). Seluruh variabel termasuk variabel tuas sekunder (secondary levers) karena letaknya jauh dari titik origin dan di atas garis diagonal. Posisi ini dapat diartikan bahwa variabel-variabel tersebut masih mempunyai sedikit pengaruh terhadap dinamika sistem jika dilakukan penanganan khusus. Dengan demikian, meskipun sifatnya relatif sulit diubah dan dapat diabaikan, namun jika pengambil kebijakan mempunyai sumber daya yang memadai, mengelola variabel-variabel ini akan sangat mendukung keberhasilan pengembangan.

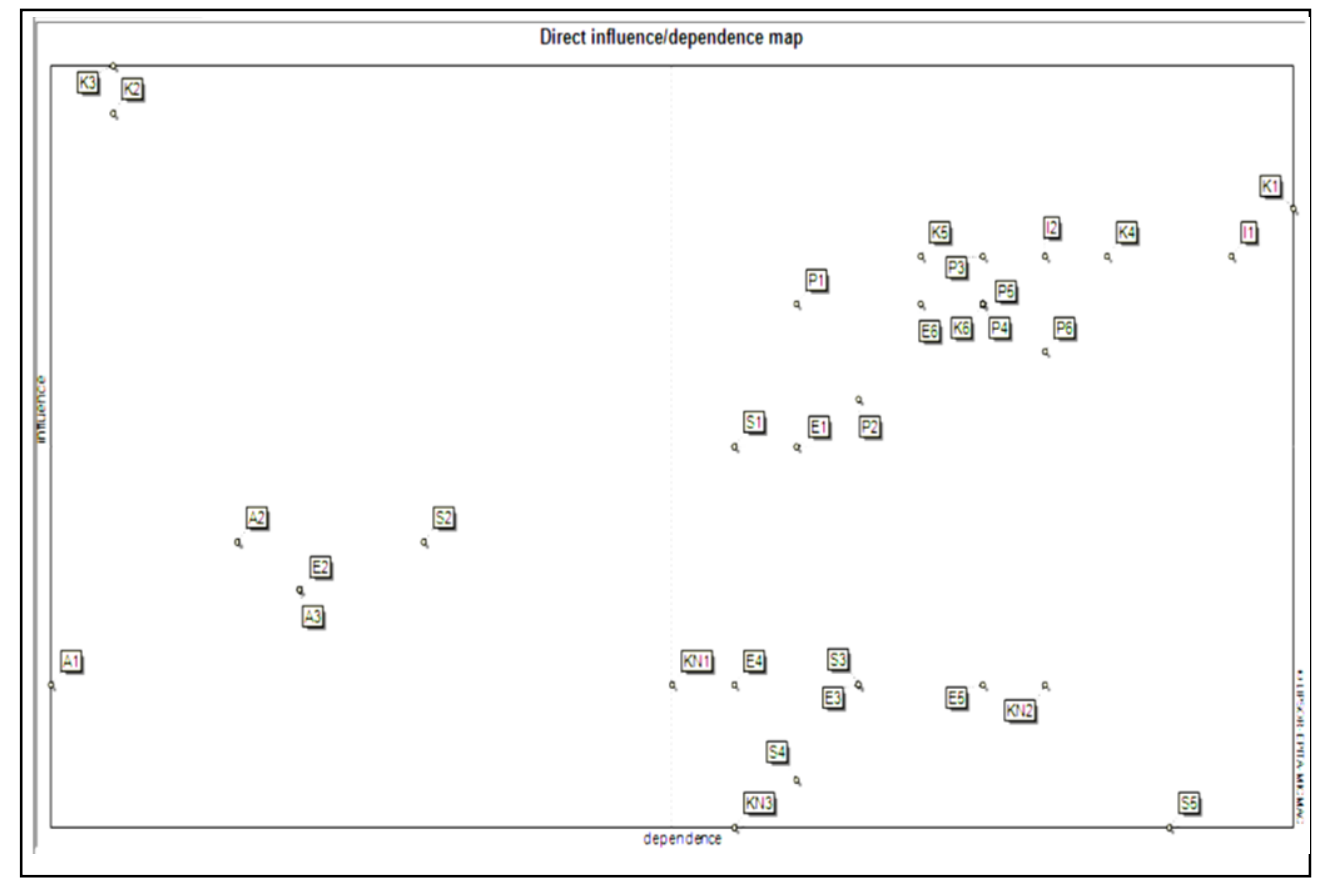

Sumber: Hasil Pengolahan Micmac, 2018

\section{Gambar 2. Peta Pengaruh-Ketergantungan Langsung}

Variabel tergantung meliputi: konservasi fungsi waduk (KN1), kelestarian hutan (KN2), konservasi kearifan lokal (KN3), pendapatan pajak (E3), pendapatan retribusi (E4), dana untuk masyarakat (E5), lapangan kerja (S3), kesejahteraan masyarakat (S4), dan kemiskinan (S5). Variabel ini merupakan output dari pengembangan kawasan ekowisata Kedung Ombo. Hasil analisis ini dapat menjadi "paksaan" kepada pengambil kebijakan untuk memberi perhatian yang lebih besar dan melaksanakan analisis mendalam terhadap variabel-variabel tersebut, karena merupakan harapan di masa depan untuk mengatasi permasalahan khususnya terkait keterbatasan lapangan kerja, kemiskinan dan kesejahteraan yang cukup masif, khususnya di lokasi-lokasi yang dekat dengan kawasan Kedung Ombo. Variabel yang lain diharapkan akan dapat terwujud dengan terbangunnya kawasan ekowisata Kedung Ombo, yaitu: peningkatan pendapatan daerah baik melalui penerimaan pajak maupun retribusi. Terkait dengan variabel K3 (terpeliharanya kearifan lokal), dapat dijelaskan bahwa vaiabel ini adalah variabel yang harus dipertahankan pada saat nantinya kawasan ekowiata Kedung Ombo terbentuk, untuk menjamin harmonisasi antara budaya baru yang berasal dari luar wilayah dengan kearifan lokal. 
Informasi tentang tipologi variabel yang telah diuraikan merupakan informasi yang sangat penting bagi pengambil kebijakan (dalam hal ini Pemerintah Kabupaten Grobogan, Sragen dan Boyolali, BBWS Pemali Juana dan Perhutani KPH Telawah dan Gundih) dalam mengembangkan kawasan ekowisata Kedung Ombo. Dengan mendasarkan pada hasil pemetaan tersebut, kebijakan pengembangan kawasan Kedung Ombo dapat diarahkan untuk fokus khususnya pada variabel-variabel yang mempunyai pengaruh paling kuat dibanding variabel lainnya, dalam hal ini variabel determinant dan variabel relay. Dengan memperhatikan temuan ini, pengambil kebijakan dapat merancang skenario untuk menggerakkan variabel-variabel tersebut dan memantau akibatnya pada variabel lainnya. Dengan mendasarkan pada pemikiran ini maka kebijakan yang diambil akan efektif dan menghindarkan timbulnya masalah di kemudian hari yang diakibatkan oleh ketidaktepatan dalam menentukan fokus kebijakan.

\section{Matrix of Indirect Influence (MII)}

Pengujian stabilitas pengelompokan variabel berdasarkan pengaruh langsung, dilakukan analisis pengaruh tidak langsung variabel dengan memerhatikan dinamika peta pengaruh dan ketergantungan variabel, jika terdapat perubahan posisi variabel yang cukup banyak dari pemetaan pengaruh langsung maka menunjukkan hasil pemetaan dan stabilitas sistem rendah. Analisis pengaruh tidak langsung dijelaskan pada matriks MII (Matrix of Indirect Influnce) yang dihasilkan dari proses transitivitas matriks pengaruh langsung (MDI).

Hasil analisis pengaruh tidak langsung menunjukkan tidak terdapat perubahan posisi variabel dari pemetaan pengaruh langsung (Gambar 3). Hal ini menunjukkan bahwa sistem dan tipologi variabel yang dihasilkan dari analisis pengaruh langsung adalah stabil. Hasil analisis pengaruh tidak langsung ini menguatkan kualifikasi variabel yang lebih memuaskan yang sangat dibutuhkan untuk pengambilan keputusan yang sahih (Stratigea \& Papadopoulou, 2013).

\section{Matrix of Potential Direct Influence (MPDI)}

Metode MicMac juga menyediakan analisis tentang pengaruh langsung potensial yang menggambarkan kemungkinan perubahan tipologi variabel jika dilakukan suatu tindakan tertentu terhadap sistem sekaligus menggambarkan kemungkinan perubahan intensitas pengaruh variabel terkait dengan waktu. Analisis ini sekaligus untuk mengofirmasi stabilitas hasil pemetaan pengaruh langsung (matriks asli). Hasil analisis pengaruh langsung potensial dijelaskan pada Matrix of Potential Direct Influence (MPDI) pada Gambar 4.

Gambar 4 menunjukkan bahwa tidak terjadi perubahan letak variabel pada peta pengaruh-ketergantungan potensial dibandingkan dengan pemetaan pengaruh langsung. Analisis ini mengonfimasi kembali hasil pemetaan pengaruh langsung. Stabilitas pemetaan variabel juga dibuktikan oleh hasil logaritma Micmac pada dua kali iterasi yang menghasilkan nilai pada iterasi pertama untuk variabel influence $93 \%$ dan variabel dependence $96 \%$, sedangkan pada iterasi kedua bernilai $100 \%$ untuk kedua variabel. Temuan ini menunjukkan bahwa pemetaan terhadap variabel-variabel strategis dalam pengembangan kawasan ekowisata Kedung Ombo adalah robust.

Secara keseluruhan temuan penelitian ini memberi implikasi kepada pengambil kebijakan bahwa harus dilakukan pemantauan secara sungguh-sungguh terhadap variabelvariabel strategis tersebut untuk mendapatkan hasil yang maksimal. Implikasi lainnya adalah harus ada upaya manajerial untuk menggerakkan variabel-variabel relay ke arah perubahan yang dikendalikan sesuai yang diinginkan oleh seluruh pemangku kepentingan. Bersamaan dengan itu, kekurangan relatif yang terdapat pada variabel-variabel relay merupakan tantangan yang harus dihadapi dan diperbaiki oleh pengambil kebijakan. 
Dengan menggunakan pendekatan ini maka kendala-kendala yang terjadi saat ini dan situasi masa depan yang tidak diharapkan sebagai akibat pengambilan kebijakan pada pengembangan kawasan ekowisata Kedung Ombo dapat diantisipasi secepat mungkin.

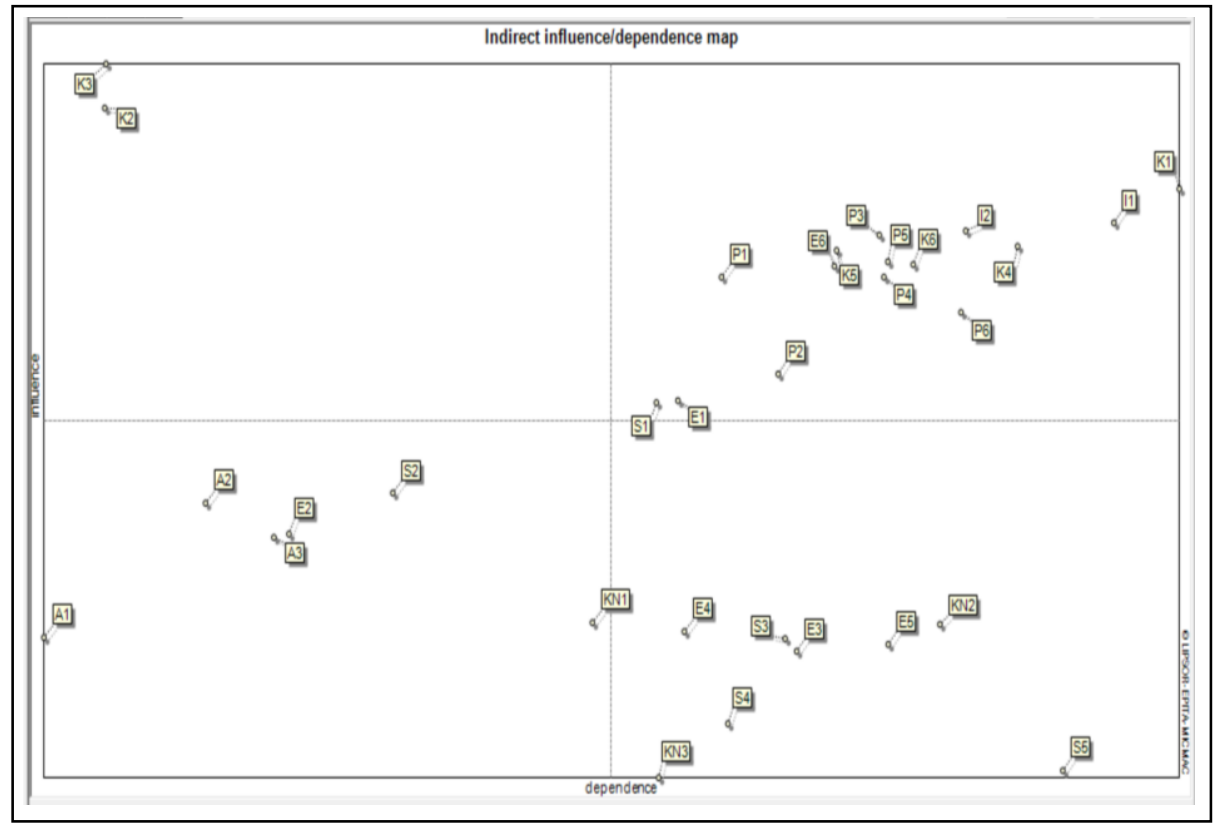

Sumber: Hasil Pengolahan Micmac, 2018

Gambar 3. Peta Pengaruh-Ketergantungan Tidak Langsung

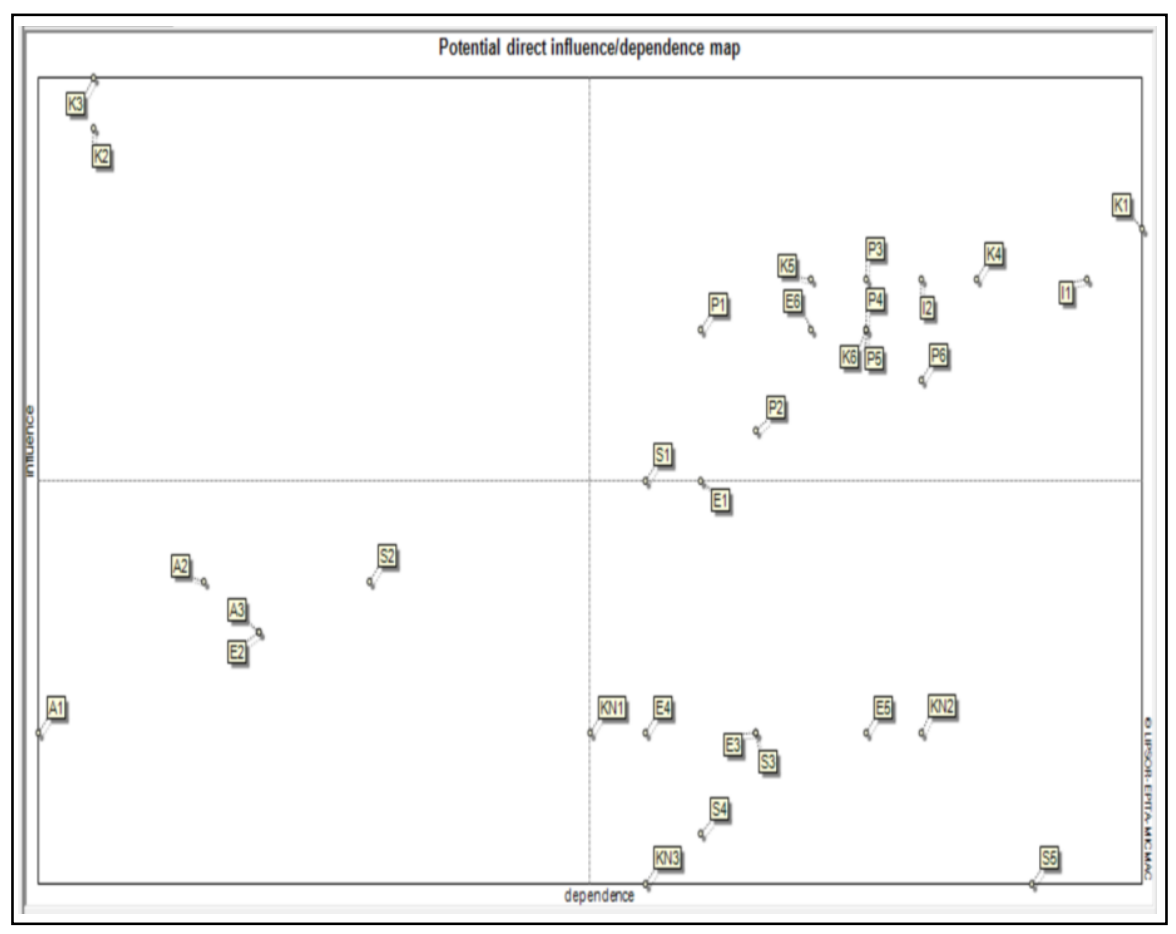

Sumber: Hasil Pengolahan Micmac, 2018

Gambar 4. Peta Pengaruh-Ketergantungan Langsung Potensial 
Tabel 2. Peringkat Variabel Berdasar Tingkat Pengaruh Langsung

\begin{tabular}{|c|c|c|c|c|c|}
\hline Rangking & Kode & Variabel & Rangking & Kode & Variabel \\
\hline 1 & $\mathrm{~K} 3$ & Regulasi & 16 & $\mathrm{~S} 1$ & Keterlibatan masyarakat \\
\hline 2 & $\mathrm{~K} 2$ & Izin khusus & 17 & E1 & Potensi usaha wisata \\
\hline 3 & K1 & Tata Kelola & 18 & $\mathrm{~A} 2$ & Daya dukung lingkungan \\
\hline 4 & K4 & Koordinasi & 19 & S2 & $\begin{array}{l}\text { Pemehaman pengembang terhadap } \\
\text { norma lokal }\end{array}$ \\
\hline 5 & K5 & Peran aparatur & 20 & A3 & Aksesibilitas \\
\hline 6 & P3 & Atraksi wisata & 21 & E2 & Kemampuan wirausaha lokal \\
\hline 7 & I1 & $\begin{array}{l}\text { Kesiapan } \\
\text { infrastruktur }\end{array}$ & 22 & $\mathrm{~A} 1$ & Keindahan alam \\
\hline 8 & $\mathrm{I} 2$ & Transportasi & 23 & S3 & Lapangan kerja \\
\hline 9 & E6 & Invetasi swasta & 24 & E3 & Pendapatan pajak \\
\hline 10 & $\mathrm{P} 1$ & Sadar wisata & 25 & E4 & Pendapatan retribusi \\
\hline 11 & P4 & Akomodasi & 26 & E5 & Dana untuk masyarakat \\
\hline 12 & P5 & $\begin{array}{l}\text { Promosi } \\
\text { pariwisata }\end{array}$ & 27 & KNI & Fungsi waduk \\
\hline 13 & K6 & Informasi & 28 & $\mathrm{KN} 2$ & Kelestarian hutan \\
\hline 14 & P6 & Jasa pariwisata & 29 & $\mathrm{~S} 4$ & Kesejahteraan masyarakat \\
\hline \multirow[t]{2}{*}{15} & P2 & Wisatawan & 30 & KN3 & Kearifan lokal \\
\hline & & & 31 & S5 & Kemiskinan \\
\hline
\end{tabular}

Sumber: Hasil Pengolahan Micmac, 2018

\section{Kesimpulan}

Penelitian ini telah berhasil mengidentifikasi variabel-variabel strategis, dan urutan skala prioritas yang menjadi variabel kunci dalam pengembangan kawasan ekowisata Kedung Ombo yang berhasil secara berkelanjutan. Variabel-variabel tersebut cukup komperehensif meliputi aspek alam, ekonomi, sosial, infrastruktur, kelembagaan, pariwisata dan konservasi. Temuan penelitian ini menjadi fondasi yang sangat kuat bagi seluruh pihak yang terlibat dalam pengambilan kebijakan untuk memfokuskan kebijakannya pada variabel-variabel yang terdapat pada kuadran determinant dan relay yang mempunyai pengaruh kuat terhadap variabel lainnya.

Dengan memahami hasil penelitian ini, seluruh pemegang kepentingan utama dapat ikut terlibat dalam pengambilan keputusan melalui sistem tata kelola yang baik yang didukung oleh kebijakan ekonomi, kebijakan sosial, kebijakan tata guna hutan dan kebijakan konservasi waduk dan lingkungan yang seimbang. Hasil pengembangan kawasan diperkirakan akan memberi dampak terhadap perluasan lapangan kerja, penurunan kemiskinan, tersedianya dana untuk masyarakat dan peningkatan kesejahteraan masyarakat.

Hasil penelitian ini berbeda dengan penelitian-penelitian lainnya terkait tentang potensi wisata Kedung Ombo. Perbedaan tersebut di antaranya adalah: (1) penggunaan analisis struktural prospektif yang mengetengahkan ide tentang pengembangan kawasan ekowisata yang bersifat usulan (belum ada pada kondisi eksisting). Sedangkan penelitian lainnya (Isnaini, 2008; Nasrudin, 2017; Ngatwanto \& Indrawati, 2018; Taofiq et al., 2015) bertujuan melakukan evaluasi terhadap obyek wisata yang ada; dan (2) penelitian ini dirancang berdasarkan perspektif kelembagaan, sehingga mencakup segala aspek yang berkaitan dengan aturan main dalam mengatur interaksi manusia dan sumber daya lainnya 
sesuai definisi kelembagaan dari North (1990) untuk mendapatkan gambaran situasi Kedung Ombo yang maksimal. Berdasarkan perspektif kelembagaan diharapkan hasilnya dapat dijadikan dasar dalam menata ulang struktur, sumber daya, kewenangan dan hubungan antara BBWS, Perhutani dan Pemerintah Kabupaten Grobogan, Sragen dan Boyolali yang selama ini menjadi salah satu penghambat keberhasilan pengembangan kawasan. Hal ini sesuai dengan pernyataan Zuo, Gusoy, \& Wall. (2017), bahwa dalam situasi rendahnya tingkat kepercayaan antaraktor, maka fokus analisis pariwisata sebaiknya mengarah pada aspek kelembagaan untuk mendorong tumbuhnya hubungan kolaboratif atau kepercayaan antarlembaga terkait adanya perbedaan kekuasaan yang mengarah pada kurangnya dukungan (Zuo et al., 2017).

Metode yang digunakan dalam penelitian ini adalah cara baru dalam membangun analisis sistematis tentang peran variabel dalam menentukan kestabilan suatu sistem (Arcade et al., 1999). Penerapan metode Micmac dalam proses pembuatan keputusan yang mempertimbangkan posisi dan intensitas variabel berdasarkan pengaruh langsung ataupun tidak langsung (dan tidak ada hubungan sebab-akibat) telah memperjelas validitas hasil penelitian dan kekuatannya dalam menentukan variabel yang paling maksimum yang harus terlibat dalam keberhasilan pengembangan kawasan ekowisata Kedung Ombo.

\section{Daftar Pustaka}

Albala, M. A., Lozano, M. J. M., \& Hernández, P. P. P. (2009). Prospective structural analysis: An application to rural development strategies. In 83rd Annual Conference of the Agricultural Economics Society (pp. 117).

Anup, K. . (2016). Ecotourism and its role in sustainable development of Nepal. In L. Butowski (Ed.), Tourism From Empirical Research Towards Practical Application. Intech Open. doi:10.5772/62308.

Arcade, J., Godet, M., Meunier, F., \& Roubelat, F. (1999). Structural analysis with the MICMAC method \& Actor's strategy with MACTOR method. Futures Research Methodology, American Council for the United Nations University: The Millennium Project, 1-69.

Benjumea-Arias, M., Castañeda, L., \& Valencia-Arias, A. (2016). Structural analysis of strategic variables through MICMAC use: Case Study. Mediterranean Journal of Social Sciences, 74), 11-19. doi:10.5901/mjss.2016.v7n4p11.

Beritelli, P., Bieger, T., \& Laesser, C. (2007). Destination governance: Using corporate governance theories as a foundation for effective destination management. Journal of Travel Research, 46(1), 96-107. doi:10.1177/0047287507302385.

Delgado-Serrano, Maria del Mar, Ambrosio-Albalá, M., \& Francisco, A. (2015). Exploration de l' analyse structurale prospective pour évaluer l' importance du développement rural territorial en Espagne et Nicaragua Résumé (Exploring prospective structural analysis to assess the relevance of rural territorial development in Spain a. Cuadernos de Desarrollo Rural, 12(76), 35-56. doi:10.11144/Javeriana.cdr1276.epsa.

Delgado-Serrano, María del Mar, Vanwildemeersch, P., London, S., Ortiz-Guerrero, C. E., Semerena, R. E., \& Rojas, M. (2016). Adapting prospective structural analysis to strengthen sustainable management and capacity building in community-based natural resource management contexts. Ecology and Society, 21(2). doi:10.5751/ES-08505-210236.

Diamantis, D. (1999). The concept of ecotourism: Evolution and Trends. Current Issues in Tourism, 2(2-3), 93122. doi: $10.1080 / 13683509908667847$.

Durance, P., Gerber, A., Bassaler, N., Menant, I., Monti, R., \& Richou, S. (2006). Strategic foresight la prospective problems and methods. Cahiers du LIPSOR.

Elmsalmi, M., \& Hachicha, W. (2013). Risks prioritization in global supply networks using MICMAC method: A real case study. In 2013 International Conference on Advanced Logistics and Transport (pp. 394-399). IEEE. doi:10.1109/ICAdLT.2013.6568491.

Erdogan, I., \& Erdogan, N. (2010). A critical evaluation of ecotourism. In Foresters' association of Turkey other publications series no:10. Yenisehir-Ankara: TODEG (Foresters' Association of Turkey Ecotourism 


\section{Analisis Tipologi Variabel Strategis pada Pengembangan Kawasan Ekowisata Kedung Ombo}

Group).

Godet, M. (2000). The art of scenarios and strategic planning. Technological Forecasting and Social Change, 65(1), 3-22. doi:10.1016/S0040-1625(99)00120-1.

Hutagalung, E. S. ., \& Sabar, A. (2015). Model prakiraan debit air dalam rangka optimalisasi pengelolaan Waduk Kedung Ombo. Jurnal Teknik Lingkungan, 21(1), 77-86.

Isnaini, A. (2008). Pengembangan wisata pintu air Waduk Kedung Ombo. Universitas Muhammadiyah Surakarta.

McKinney, T. (2016). Ecotourism. In The International Encyclopedia of Primatology (pp. 1-2). Hoboken, NJ, USA: John Wiley \& Sons, Inc. doi:10.1002/9781119179313.wbprim0120.

Nasrudin, M. (2017). Pemanfaatan objek wisata Waduk Kedung Ombo sebagai sumber belajar outdoor study mata pelajaran geografi pada siswa kelas X IPS di SMA Negeri 1 Godong Kabupaten Grobogan tahun 2017. Universitas Negeri Semarang.

Ngatwanto, I., \& Indrawati, I. (2018). “The freshwater world” Waduk Kedung Ombo sebagai pusat wisata edukasi ekosistem air tawar dengan pendekatan neo vernacular design. Universitas Muhammadiyah Surakarta.

North, D., C. (1990). Institutional, instituional change and economic performance (59262nd Ed). Cambridge University Press.

Rodríguez-Díaz, M., \& Espino Rodríguez, T. (2016). Determining the sustainability factors and performance of a tourism destination from the stakeholders' perspective. Sustainability, 8(9), 951. doi:10.3390/su8090951.

Sindiga, I. (1999). Alternative tourism and sustainable development in Kenya. Journal of Sustainable Tourism, 72), 108-127. doi:10.1080/09669589908667330.

Stratigea, A., \& Papadopoulou, C. - A. (2013). Foresight analysis at the regional level - A participatory methodological framework. Journal of Management and Strategy, 4(2), 1-16. doi:10.5430/jms.v4n2p1.

Taofiq, T., Asrori, M., \& Iswati, T. Y. (2015). Agrowisata sebagai pengembangan wisata sebagai pengembangan kawasan Waduk Kedung Ombo dengan pendekatan arsitektur ekologis. Arsitektura, 13(2). doi:10.20961/arst.v13i2.15660.

Zuo, B., Gusoy, D., \& Wall, G. (2017). Residents' support for red tourism in China: The moderating effect of central government. Annals of Tourism Research, 64, 51-63. doi:10.1016/j.annals.2017.03.001. 